Journal of Animal and Veterinary Advances 11 (1): 141-147, 2012

ISSN: $1680-5593$

(C) Medwell Journals, 2012

\title{
Effects of Production System, Breed, Parity and Stage of Lactation on Milk Composition of Dromedary Camels in Saudi Arabia
}

\author{
${ }^{1,3}$ Riyadh S. Aljumaah, ${ }^{1}$ Faris F. Almutairi, ${ }^{2}$ Elsayed Ismail, ${ }^{1}$ Mohammad A. Alshaikh, \\ ${ }^{1}$ Ahmad Sami and ${ }^{3}$ Moez Ayadi \\ ${ }^{1}$ Department of Animal Production, ${ }^{2}$ Department of Food and Nutrition Sciences, \\ College of Food and Agriculture Sciences, King Saud University, \\ P.O. Box 2460, 11451 Riyadh, Saudi Arabia \\ ${ }^{3}$ Center of Excellence in Biotechnology Research, \\ P.O. Box 2455, 11451 Riyadh, Saudi Arabia
}

\begin{abstract}
The present study was carried out to investigate the effects of production system, breed, parity and stage of lactation on milk composition of dromedary camel. Samples of camel milk were collected from 191 healthy she-camels from four different indigenous breeds (Majahiem, Maghatier, Shoal and Soffer). Milk samples from each quarter were collected during the afternoon milking and California Mastitis Test (CMT) was used as an indirect measure of the health status of the udder quarter. The highest significant concentrations of protein, lactose and Solid None Fat (SNF) were recorded for the seminomadic system and Soffer breed. Moreover, the mean fat, protein, lactose and SNF values were significantly the highest during the first stage of lactation. Protein, lactose and SNF values were gradually decreased by the subsequent parity. Settled system and Shoal breed had the significant high content of fat compared to their counterparts. However, insignificant differences in fat percentage during parity were observed. Fat content was significantly high at the first stage of lactation in comparison with the second and third ones. Seminomadic system and in Maghatier breed significantly increased the $\mathrm{Ca}^{++}$and $\mathrm{K}^{+}$values compared to their counterparts. The $\mathrm{Na}: \mathrm{K}$ ratio was also affected by production system. The results indicated that variations in camel milk composition were mainly attributed to factors such as production system, breed, parity and stage of lactation. Therefore, those factors should be taken into account when nutritional and technological aspects of camel milk need to be evaluated.
\end{abstract}

Key words: Camel milk, breed, management system, parity, lactation, Saudi Arabia

\section{INTRODUCTION}

Dromedary camels (Camelus drmedaruis) can survive and produce considerable amount of milk during recurrent and prolonged hot and dry environment (Bekele et al., 2011). Thus, camel milk is considered one of the most valuable food sources for nomadic people in arid and semi-arid areas and has been consumed for centuries due to its nutritional values and medicinal properties (Kenzhebulat et al., 2000; Mal et al., 2006; Lorenzen et al., 2011). It is considered to have anti-cancer (Magjeed, 2005), hypo-allergic (Shabo et al., 2005) and anti-diabetic (Agrawal et al., 2003, 2011) properties. The high content of unsaturated fatty acids of the camel milk may enhances its overall nutritional quality (Karray et al., 2005; Konuspayeva et al., 2008; Ayadi et al., 2009).

Studies on the yield and composition of camel milk were varied in many countries (Khaskheli et al., 2005). Camel milk composition was found to be less stable than other species such as bovine. Previous findings pointed out that the variation in camel milk composition could be attributed to many factors such as analytical measurement procedures, geographical locations, feeding conditions, type of samples and breeds in addition to other factors including milking frequency, stage of lactation and parity (Iqbel et al., 2001; Ayadi et al., 2009; Al-Haj and Al- Kanhal, 2010; Hammadi et al., 201 0; Aljumaah et al., 2011). However, geographical origin and seasonal variations were found to be the most effective factors on camel milk constituents (Khaskheli et al., 2005). Konuspayeva et al. (2009) reported high variability in camel milk components and chemical composition during different lactation stages. The mean values of camel milk composition $(\%)$ reported over the past 30 years were: $3.5 \pm 0.1 ; 3.1 \pm 0.5 ; 4.4 \pm 0.7 ; 0.79 \pm 0.07$ and $11.9 \pm 1.5$ for fat, protein, lactose, ash and total solids, respectively (Al-Haj and Al-Kanhal, 2010). Generally, daily milk yield of camel was ranged between 3.5-25.0 L (Khaskheli et al.,

Corresponding Author: Riyadh Aljumaah, Department of Animal Production, College of Food and Agriculture Sciences, King Saud University, P.O. Box 2460, 11451 Riyadh, Saudi Arabia 
2005). The recent camel population in Saudi Arabia showed approximately 800,000 head of different indigenous breeds. Indigenous camels in Saudi Arabia can be classified into different ecotypes or breeds including: Majahiem, Maghatier, Shoal, Soffer and others (Almutairi, 2009). Three major production systems: nomadic, semi-grazing and settled systems are practiced in the kingdom (Saoud et al., 1988; Gaili et al., 2000). Total milk production of camels in the Kingdom of Saudi Arabia ranges between 2,500-4,900 L year ${ }^{-1}$ (Gaili et al., 2000; Aljumaah et al., 2011).

The composition of camel's milk had been studied under different conditions (Sawaya et al., 1984; Abu-Lehia, 1987; El-Amin and Wilcox, 1992; Mehaia et al., 1995). However, there is limited information about the factors affecting milk composition of camels in Saudi Arabia. Therefore, the aim of this study was to investigate the effects of production system, breed, parity and stage of lactation on the camel milk composition in Saudi Arabia.

\section{MATERIALS AND METHODS}

Samples collection: Camel milk samples were collected from different areas in Riyadh province, Saudi Arabia during July 2007 to May 2008. A total of 764 quarter milk samples were collected from 191 healthy she-camels of four indigenous breeds, Majahiem, Maghatier, Shoal and Soffer. Numbers of camels sampled from each breed were $69,49,39$ and 34, respectively. The mean of milk production for the different breeds in the studied herds ranged between $4-15 \mathrm{~kg}$ day $^{-1}$. Milk samples (100 mL) were collected from each animal during the afternoon milking in sterilized bottles after removing the first drops. Signs of mastitis and physical injury of udders were examined and the milk samples were observed for grossly visible abnormalities. California Mastitis Test (CMT) was used as an indirect measure of the udder health status. Samples were immediately cooled to $4^{\circ} \mathrm{C}$, transported to the laboratory and kept frozen at $-20^{\circ} \mathrm{C}$ until the subsequent analysis. Information about parity, stage of lactation, breed, production systems, milking method, suckling system and udder status of the sampled she-camels were recorded.

Production systems were divided into three types; nomadic, seminomadic and settled systems. In nomadic system, the animals spend all time in pasture (around $100 \mathrm{~km}$ of Riyadh region) while suckling of calves was open (4-6 time day ${ }^{-1}$ ). In the seminomadic system, animals graze the natural pasture only during spring (suckling of calves was open) and were housed in pens during the rest of the year. In seminomadic system, animals were hand milked twice a day (morning and afternoon). Daily ration consists of a mixture of Alfalfa and barley hay supplemented by wheat bran. In nomadic and seminomadic systems animals have restricted access to water. In settled system, the entire herd was kept in barns or farm premises, all the year. Feeding and milking procedure of camels were similar to seminomadic system. Ad libitum access to clean water was ensure by use of water tanks. According to parity, the collected samples were divided into four categories; first, second, third and fourth or more. Stage of lactation was also divided into three stages; first (from birth to 3 months) second (from 3 6 months) and third (from 6 months to the end of milking season) stage.

Chemical composition: Major fat, protein, lactose and Solid-Non-Fat (SNF) percentages were analyzed using a Lacto Star milk scanner (Funke-Gerber, Labortechnik $\mathrm{GmbH}$, Berlin, Germany). Milk minerals $\left(\mathrm{Ca}^{++}, \mathrm{Na}^{+}\right.$and $\left.\mathrm{K}^{+}\right)$ were determined using atomic absorption spectrometry (Analyst spectrophotometer 300, Perkin-Elmer Inc, Shelton, CT, USA). The $\mathrm{pH}$ values were determined using $\mathrm{pH}$ meter (Microprocessor $\mathrm{pH}$ Meter, $\mathrm{pH} 211$, Portugal).

Statistical analyses: Only samples with no evidence of subclinical mastitis were included in this trail $(n=402)$. Data were analyzed using the General Linear Model (GLM) procedure in SAS Version 8.2 in 2002. Differences among means were detected using Duncan's multiple range test when significant differences existed (Steel et al., 1997).

\section{RESULTS AND DISCUSSION}

A total of 402 samples with no evidence of subclinical mastitis were included in this trail.

Milk composition: The mean values of camel milk constituents that influenced by production system and breed are shown in Table 1. Camels reared in nomadic, seminomadic and settled systems represented 26,61 and $13 \%$ of the total animals sampled, respectively. Results revealed that camel milk composition was significantly affected by production system $(\mathrm{p}<0.05)$. The highest percentage of protein (3.60), lactose (5.25) and SNF (9.61) were recorded for the semi nomadic system. In contrast, these components were the lowest under the nomadic system. The fat content was higher in the settled system than nomadic and seminomadic production systems (3.16 vs. 2.94 and $2.86 \%$, respectively). These decreases in values of camel fat components of the nomadic and seminomadic systems might be due to insufficient nutrient 
Table 1: Means \pm Standard Deviation (SD) of camel milk components (\%) as influenced by production systems and breeds

\begin{tabular}{|c|c|c|c|c|c|}
\hline \multirow[b]{2}{*}{ Factors } & \multirow{2}{*}{$\begin{array}{c}\text { Quarter } \\
\text { No. }\end{array}$} & \multicolumn{4}{|l|}{ Percentage } \\
\hline & & Fat & Protein & Lactose & SNF \\
\hline \multicolumn{6}{|c|}{ Production system } \\
\hline Nomadic & 42 & $2.94 \pm 0.94^{\mathrm{ab}}$ & $3.11 \pm 0.36^{c}$ & $4.59 \pm 0.66^{c}$ & $8.30 \pm 0.94^{c}$ \\
\hline Seminomadic & 305 & $2.86 \pm 0.64^{b}$ & $3.60 \pm 0.38^{\mathrm{a}}$ & $5.25 \pm 0.58^{\mathrm{a}}$ & $9.61 \pm 1.03^{\mathrm{a}}$ \\
\hline Settled & 55 & $3.16 \pm 1.12^{\mathrm{a}}$ & $3.41 \pm 0.28^{b}$ & $4.93 \pm 0.47^{b}$ & $9.11 \pm 0.76^{b}$ \\
\hline \multicolumn{6}{|l|}{ Breed } \\
\hline Majahiem & 152 & $2.84 \pm 0.84^{b}$ & $3.48 \pm 0.47^{\circ}$ & $5.07 \pm 0.28^{b}$ & $9.30 \pm 1.24^{b}$ \\
\hline Maghatier & 125 & $2.79 \pm 0.63^{b}$ & $3.47 \pm 0.27^{b}$ & $5.07 \pm 0.44^{b}$ & $9.29 \pm 0.63^{b}$ \\
\hline Shoal & 61 & $3.26 \pm 0.81^{\mathrm{a}}$ & $3.25 \pm 0.29^{b}$ & $5.12 \pm 0.42^{b}$ & $9.39 \pm 0.77^{b}$ \\
\hline Soffer & 64 & $2.96 \pm 0.71^{b}$ & $3.70 \pm 0.51^{\mathrm{a}}$ & $5.44 \pm 0.78^{\mathrm{a}}$ & $9.89 \pm 1.37^{\mathrm{a}}$ \\
\hline
\end{tabular}

Table 2: Means \pm Standard Deviation (SD) of camel milk components (\%) as influenced by parity and stage of lactation

\section{Percentage}

\begin{tabular}{|c|c|c|c|c|c|}
\hline actors & arter & Fat & Protein & Lactose & SNF \\
\hline \multicolumn{6}{|l|}{ Parity } \\
\hline 1 & 89 & $2.98 \pm 0.74$ & $3.64 \pm 0.45^{\mathrm{a}}$ & $5.30 \pm 0.71^{\mathrm{a}}$ & $9.73 \pm 1.30^{\circ}$ \\
\hline 2 & 82 & $2.98 \pm$ & $3.50=$ & $5.08 \pm 0.50^{b c}$ & $9.34 \pm 0.89^{\circ}$ \\
\hline 3 & 131 & $2.87 \pm$ & 3.53 & $5.17 \pm 0.70^{\mathrm{ab}}$ & $9.42 \pm 1.12^{\circ}$ \\
\hline$\leq 4$ & 100 & $2.83 \pm 0.73$ & $3.43 \pm 0.29^{\circ}$ & $4.99 \pm 0.44^{c}$ & $9.16 \pm 0.78^{c}$ \\
\hline \multicolumn{6}{|c|}{ Stage of lactation } \\
\hline 1 & 95 & $3.25 \pm 0.78^{\mathrm{a}}$ & $3.78=$ & $5.50 \pm 0.78^{a}$ & $10.09 \pm 1.14$ \\
\hline 2 & 182 & $2.78 \pm 0.54^{b}$ & $3.52 \pm 0.30^{b}$ & $5.14 \pm 0.48^{b}$ & $9.41 \pm 0.80^{b}$ \\
\hline & 125 & $2.83 \pm 0.95^{b}$ & $3.33 \pm 0.29^{c}$ & $4.86 \pm 0.50^{\circ}$ & $8.89 \pm 0.77$ \\
\hline
\end{tabular}

${ }^{\mathrm{a}-\mathrm{c}}$ Means with different letters in the same column are significantly different at $\mathrm{p} \leq 0.05$; "Stage of lactation; 1) from the birth to 3 months; 2) from 3-6 months; 3 ) from 6 months to the end of lactation season

supplements and limitation of animals' health care in comparison with those in the settled system. These results partly agreed with those previously reported in Bedouin camels under semi nomadic system (Guliye et al., 2000). On the other hand, the obtained results disagree with previous results reported by Haddadin et al. (2008) where the milk composition in camels was found to be independent of grazing system. Konuspayeva et al. (2009) and Al-Haj and Al-Kanhal (2010) reported that camel milk composition was influenced by regional differences including feeding conditions.

Significant differences among the four studied breeds $(\mathrm{p}<0.01)$ in the chemical milk composition were observed. This result agree with those of other researchers (Alshaikh and Salah, 1994; Gaili et al., 2000; Khaskheli et al., 2005; Konuspayeva et al., 2009; Ereifej et al., 2011) who reported that camel milk components were significantly affected by the breed of lactating camels. The Soffer camels had the highest contents of protein, lactose and SNF (3.70, 5.44 and $9.89 \%$, respectively). The fat percentage of Shoal camel milk recorded the highest value ( $3.26 \%)$. In the contrary, Mohamed illustrated that fat content of Majahiem camel milk was recorded the highest value among all breeds. However, insignificant differences in milk constituents were found between Majahiem and Maghatier breeds. These results are consistent with those of Gaili et al. (2000) who found similarities between camel milk components of Majahiem and Maghatier but reported differences in these components between these two camel breeds and Aork camel breed. Table 2 shows the effect of parity and stage of lactation on camel milk constituents. Results showed significant differences $(\mathrm{p}<0.05)$ in protein, lactose and SNF contents in different parities. Where first lactation was distinguished with high mean values of protein, lactose and SNF percentages (3.64, 5.30 and $9.73 \%$, respectively). Meanwhile, the mean values of milk constituents were gradually decreased by the subsequent parity but there were no significant differences among camel milk constituents during the second and the third lactation. Starting from the fourth lactation, milk constituents were significantly decreased. No significant difference in fat content with parity but there was a slight decrease in fat percentage from $2.98-2.83 \%$ from first to fourth or more lactation. In contrast, Zeleke (2007) mentioned that the effect of parity on fat content of camel milk was significant. The milk in third parity had the highest fat content $(5.32 \%)$. The highest level of lactose was observed in the first parity $(5.3 \%)$. This result is concordant with those of Zeleke (2007) who reported that the highest lactose content was recorded in the first lactation. This observation probably explains the common understanding among camel milk producers that camel milk is sweeter during first lactation than other subsequent lactations. Camel milk composition is affected significantly $(p<0.05)$ by the stage of lactation. Fat, protein, lactose and SNF contents were higher during the first stage of lactation than second and third ones. The obtained results followed the same trend reported by Alshaikh and Salah (1994), Haddadin et al. (2008) and Zeleke (2007) who found that values of fat, protein and total solids were highest during the first 6 months of lactation. Camel milk constituents were gradually decreased during the second and third stage of lactation. Fat, protein, lactose and SNF contents were significantly decreased during the third stage of lactation. This decrease may be due to the increase in the milk water content during the last stage of lactation. These results confirm those of Gaili et al. (2000) and Zeleke (2007) who demonstrated that total solids of camel milk decreased from $11.7 \%$ in the first stage of lactation to $10.1 \%$ by the end of lactation and that fat content of camel milk was gradually decreased with the progress of the stage of lactation.

Minerals content: The $\mathrm{pH}$ value and mineral content are shown in Table 3 and 4 . Generally, Calcium $\left(\mathrm{Ca}^{++}\right)$content 


\begin{tabular}{|c|c|c|c|c|c|}
\hline Factors & Quarter No. & $\mathrm{Ca}^{++}$ & $\mathrm{Na}^{+}$ & $\mathrm{K}^{+}$ & $\mathrm{pH}$ \\
\hline \multicolumn{6}{|c|}{ Production system } \\
\hline Nomadic & 42 & $84.14 \pm 14.00^{\circ}$ & $33.22 \pm 11.58^{b}$ & $77.35 \pm 28.39^{b}$ & $6.32 \pm 0.22^{b}$ \\
\hline Seminomadic & 305 & $101.03 \pm 21.32^{\mathrm{a}}$ & $35.32 \pm 10.03^{b}$ & $94.49 \pm 28.42^{\mathrm{a}}$ & $6.40 \pm 0.14^{a}$ \\
\hline Settled & 55 & $93.27 \pm 24.80^{b}$ & $43.86 \pm 26.10^{a}$ & $91.12 \pm 33.48^{\mathrm{a}}$ & $6.32 \pm 0.12^{b}$ \\
\hline \multicolumn{6}{|l|}{ Breed } \\
\hline Majahiem & 152 & $90.54 \pm 17.15^{c}$ & $38.89 \pm 15.93^{\mathrm{a}}$ & $91.21 \pm 27.29^{b}$ & $6.37 \pm 0.19^{b}$ \\
\hline Maghatier & 125 & $105.34 \pm 26.33^{\mathrm{a}}$ & $36.10 \pm 15.11^{\mathrm{ab}}$ & $99.30 \pm 32.03^{\mathrm{a}}$ & $6.41 \pm 0.12^{\mathrm{a}}$ \\
\hline Shoal & 61 & $93.83 \pm 22.54^{\mathrm{cb}}$ & $33.15 \pm 09.80^{b}$ & $78.09 \pm 21.28^{c}$ & $6.40 \pm 0.12^{b}$ \\
\hline Sofer & 64 & $98.12 \pm 18.02^{b}$ & $34.04 \pm 10.77^{\circ}$ & $89.28 \pm 32.22^{b}$ & $6.37 \pm 0.15^{b}$ \\
\hline
\end{tabular}

${ }^{a-c}$ Means with different letters in the same column are significantly different at $p \leq 0.05$

Table 4: Means \pm Standard Deviation (SD) of camel milk minerals $(\mathrm{mg} / 100 \mathrm{~g})$ and $\mathrm{pH}$ as affected by parity and stage of lactation Quarter

\begin{tabular}{|c|c|c|c|c|c|}
\hline$\underline{\text { Factors }}$ & No & $\mathrm{Ca}^{++}$ & $\mathrm{Na}^{+}$ & $\mathrm{K}^{+}$ & $\mathrm{pH}$ \\
\hline \multicolumn{6}{|l|}{ Parity } \\
\hline 1 & 89 & $93.27 \pm 15.85$ & $34.79 \pm 14.42$ & $85.89 \pm 29.38^{b c}$ & $6.42 \pm 0.13^{\mathrm{a}}$ \\
\hline 2 & 82 & 97.9 & $34.61 \pm 15.27$ & $84.60 \pm 25.25^{\mathrm{c}}$ & $6.42 \pm 0.14^{\mathrm{a}}$ \\
\hline 3 & 131 & 97.02 & 32.35 & 82.4 & $6.39 \pm 0.18^{\mathrm{a}}$ \\
\hline$\leq 4$ & 100 & $99.43=$ & 38.96 & $101.55 \pm 33.78^{a}$ & $6.32 \pm 0.18^{b}$ \\
\hline \multicolumn{6}{|c|}{ Stage of lactation ${ }^{*}$} \\
\hline 1 & 95 & $94.58 \pm 2.700^{b}$ & $31.92 \pm 17.09^{b}$ & $77.72 \pm 31.53^{c}$ & $6.42 \pm 0.17^{\circ}$ \\
\hline 2 & 182 & $103.32 \pm 24.25^{\mathrm{a}}$ & $32.27 \pm 12.10^{b}$ & $98.85 \pm 28.19^{a}$ & $6.39 \pm 0.14^{\mathrm{ab}}$ \\
\hline 3 & 125 & $91.80 \pm 17.89^{b}$ & $38.17 \pm 13.48^{\mathrm{a}}$ & $98.85 \pm 27.90^{b}$ & $6.37 \pm 0.15^{b}$ \\
\hline
\end{tabular}

${ }^{\mathrm{ac}} \mathrm{Means}$ with different letters in the same column are sionificantly different at $\mathrm{p} \leq 0.05$; "Stage of lactation; 1) from the birth to 3 months, 2) from 3-6 months, 3) from 6 months to the end of parity

ranged from $84.14-105.34 \mathrm{mg} / 100 \mathrm{~g}$ with an average of $94.74 \pm 20.61 \mathrm{mg} / 100 \mathrm{~g}$. Sodium $\left(\mathrm{Na}^{+}\right)$content ranged from $31.92-43.86 \mathrm{mg} / 100 \mathrm{~g}$ with an average of $37.89 \pm 14.35 \mathrm{mg} / 100 \mathrm{~g}$ while potassium $\left(\mathrm{K}^{+}\right)$content ranged from $77.35-101.55 \mathrm{mg} / 100 \mathrm{~g}$ with an average of $89.45 \pm 28.21 \mathrm{mg} / 100 \mathrm{~g}$. The $\mathrm{pH}$ values ranged from 6.32-6.42 with an average value of $6.37 \pm 0.15$. High variability was observed in the published data regarding the mineral content of camel milk (Sawaya et al., 1984; Dukwal et al., 2007; Haddadin et al., 2008; Ayadi et al., 2009). These variations could be attributed to breed differences, intervals between milking; feeding, analytical procedures and water intake (Haddadin et al., 2008; Mehaia et al., 1995). In this study, the value of $\mathrm{Ca}^{++}$ content was in agreement with that reported by Sawaya et al. (1984) and Ayadi et al. (2009) but was higher than that reported by El-Amin and Wilcox (1992). $\mathrm{Na}^{+}$content was close to those of El-Amin and Wilcox (1992) while $\mathrm{K}^{+}$content was similar to that recorded by El-Amin and Wilcox (1992) and Sawaya et al. (1984) but lower than that reported by Ayadi et al. (2009). Milk $\mathrm{pH}$ values in this study followed the same trend reported by Sawaya et al. (1984) and Hammadi et al. (2010). Table 3 shows the effects of production systems and breed on the contents of $\mathrm{Ca}^{++}, \mathrm{Na}^{+}, \mathrm{K}^{+}$and $\mathrm{pH}$ of camel milk. Significant differences $(\mathrm{p} \leq 0.01)$ among the contents of milk minerals as well as $\mathrm{pH}$ values by different production system were found. The highest $\mathrm{pH}$ value (6.40) was recorded in the semi nomadic system and the lowest (6.32) in the settled system. Average $\mathrm{Ca}^{++}$and $\mathrm{K}^{+}$ values were highest (101.03 and $94.49 \mathrm{mg} / 100 \mathrm{~g}$, respectively) in the semi nomadic system whereas the average of $\mathrm{Na}^{+}$was significantly higher $(\mathrm{p} \leq 0.01)$ in the settled system than other production systems. Generally, the values of camel milk minerals were lowest in the nomadic system compared to the other systems and this could be attributed to insufficient nutrients supplements and limitation of animals' health care in this system compared with other management systems.

The present results revealed that $\mathrm{Na}: \mathrm{K}$ ratio was not affected by breeds, stage of lactation or parity. However, significant effect on $\mathrm{Na}: \mathrm{K}$ ratio $(\mathrm{p} \leq 0.05)$ was observed according to the production system. The calculated Na:K ratios were $1: 2.3,1: 2.5$ and $1: 2.1$ for nomadic, semi nomadic and settled system, respectively. The milking management (numbers of suckling or milking per day) applied in these different production systems in the present research apparently affected the major mineral content in camels milk. Variations in mineral concentration in milk and increments in Na: $\mathrm{K}$ ratio has been described in dairy goats (Boutinaud et al., 2003) and dairy cows (Stelwagen et al., 1994; Delamaire and Guinard-Flament, 2006) when milked once per day. Extended milking intervals may negatively affect milk composition and cheese yield as a result of increasing protease activity in milk (Bastian and Brown, 1996). Alterations in the $\mathrm{Na}: \mathrm{K}$ ratio have been shown to interfere with a number of intracellular processes. Increased $\mathrm{Na}: \mathrm{K}$ ratio reduced mammary protein synthesis in dairy goats (Stelwagen et al., 1999). In dairy camels, this regulatory mechanism seems not to operate (Ayadi et al., 2009). Instead, this difference might be related to the adaptation of the camels to the dessert conditions. Further research is needed to explore in depth the consequence of this difference. Significant differences $(\mathrm{p}<0.01)$ in mineral content of camel milk were detected among the four breeds. $\mathrm{Ca}^{++}$and $\mathrm{K}^{+}$contents recorded the highest values (105.34 and $99.30 \mathrm{mg} / 100 \mathrm{~g}$, respectively) in Maghatier. The $\mathrm{Ca}^{++}$content was close to that reported by. The $\mathrm{K}^{+}$content was less than that found in Maghatier milk. The highest value of $\mathrm{Na}^{+}$content was $38.89 \mathrm{mg} / 100 \mathrm{~g}$ in Majahiem milk and the lowest value was 
$(33.15 \mathrm{mg} / 100 \mathrm{~g})$ in Shoal milk. These results are very close to those reported by El-Amin and Wilcox (1992) who found that $\mathrm{Na}^{+}$content in Majahiem milk $43.10 \mathrm{mg} / 100 \mathrm{~g}$. The $\mathrm{pH}$ value was significantly higher $(\mathrm{p}<0.01)$ in Maghatier and Shoal camel milk than in Majahiem and Soffer milk giving, respective values of $6.41,6.40,6.37$ and 6.37. Sawaya et al. (1984) stated that $\mathrm{pH}$ values of Majahiem, Maghatier and Hamra camel milk were 6.49, 6.65 and 6.65 , respectively. These values were higher than those found in the present study while $\mathrm{pH}$ of Majahiem milk was comparable in the two studies.

Table 4 shows the effect of parity and stage of lactation on the major mineral contents and $\mathrm{pH}$ of camel milk. The results showed that $\mathrm{Ca}^{++}$and $\mathrm{Na}^{+}$contents were not affected by parity and ranged from 93.27-99.43 and $34.79-38.96 \mathrm{mg} / 100 \mathrm{~g}$, respectively. These results disagree with those of who reported that $\mathrm{Na}^{+}$content was greatly affected by parity.

Potassium content was lower in the third lactation than the fourth and more subsequent lactations. The $\mathrm{pH}$ was also significantly $(\mathrm{p}<0.05)$ affected by parity with $\mathrm{pH}$ values of 6.42 during the first lactation decreasing to 6.32 during the fourth lactation or more. Moreover, camel milk minerals content and $\mathrm{pH}$ were significantly affected ( $\mathrm{p} \leq 0.01)$ by the stage of lactation with the highest content of $\mathrm{Ca}^{++}(103.32 \mathrm{mg} / 100 \mathrm{~g})$ being recorded during the second stage of lactation and the lowest value $(91.80 \mathrm{mg} / 100 \mathrm{~g})$ during the last stage of lactation. The $\mathrm{Na}^{+}$ and $\mathrm{K}^{+}$contents were relatively low in the first stage (31.92 and $77.72 \mathrm{mg} / 100 \mathrm{~g}$, respectively) and increased during subsequent stages. The $\mathrm{pH}$ of camel milk was also significantly affected by the stage of lactation with value decreasing with the progress of lactation stage hence, the highest $\mathrm{pH}$ value was 6.42 in the first stage and reached 6.37 in the third stage. It seems that changes in mineral content and $\mathrm{pH}$ values of camel milk depended on productions systems, breed variations, parity and stage of lactation. This agrees with Farah (1996) who pointed out that minerals composition of camel's milk was affected by factors such as stage of lactation and udder health status. However, few data are available on mineral composition of camels' milk (Dell'Orto et al., 2000).

\section{CONCLUSION}

The present study emphasizes that the variations in camel milk composition could be attributed to such factors as production systems, breed differences, parity and stage of lactation. The highest contents of protein, lactose and SNF were recorded for the seminomadic system and Soffer breed at first stage of lactation and decreased by parity. The highest content of fat $\%$ was recorded in settled system and Shoal breed. The highest values of $\mathrm{Ca}^{++}$and $\mathrm{K}^{+}$were recorded in the seminomadic system and in Maghatier. Therefore, factors that cause variation in milk composition should be taken into account when nutritional and technological aspects of dromedary camel milk are evaluated.

\section{ACKNOWLEDGEMENTS}

The researchers thanks the Deanship of Scientific Research at King Saud University for funding this research through the research group project No. RGPVPP-042. The researchers would also like to appreciate camel owners for their cooperation during the study.

\section{REFERENCES}

Abu-Lehia, I.H., 1987. Composition of camel milk. Milchwissenschaft, 42: 368-371.

Agrawal, R.P., S. Jain, S. Shah, A. Chopra and V. Agarwal, 2011. Effect of camel milk on glycemic control and insulin requirement in patients with type 1 diabetes: 2-years randomized controlled trial. Eur. J. Clin. Nutr., 65: 1048-1052.

Agrawal, R.P., S.C. Swami, R. Beniwal, D.K. Kochar, M.S. Sahani, F.C. Tuteja and S.K. Ghouri, 2003. Effect of camel milk on glycemic control, risk factors and diabetes quality of life in type-1 diabetes: A randomized prospective controlled study. J. Camel Pract. Res., 10: 45-50.

Al-Haj, O.A. and H.A. Al-Kanhal, 2010. Compositional, technological and nutritional aspects of dromedary camel milk. Int. Dairy J., 20: 811-821.

Aljumaah, R.S., F.F. Almutairi, M.A. Ayadi, M.A. Alshaikh, A.M. Aljumaah and M.F. Hussein, 2011. Factors influencing the prevalence of subclinical mastitis in lactating dromedary camels in riyadh region, Saudi Arabia. Trop. Anim. Health Pro. (In Press).

Almutairi, F.F., 2009. Studies on somatic cell count and some constituents of camel's milk. MSc. Thesis, King Saud University.

Alshaikh, M.A. and M.S. Salah, 1994. Effect of milking interval on secretion rate and composition of camel milk in late lactation. J. Dairy Res., 61: 451-456.

Ayadi, M., M. Hammadi, T. Khorchani, A. Barmat, M. Atigui and G. Caja, 2009. Effects of milking interval and cisternal udder evaluation in Tunisian maghrebi dairy dromedaries (Camelus dromedarius L.). J. Dairy Sci., 92: 1452-1459. 
Bastian, E.D. and R.J. Brown, 1996. Plasmin in milk and dairy products: An update. Int. Dairy J., 6: 435-457.

Bekele, T., N. Lunderheim and K. Dahlborn, 2011. Milk feeding and feeding behavior in the camel (Camelus dromedaries) during 4 watering regimens. J. Dairy Sci., 94: 1310-1317.

Boutinaud, M., C. Rousseau, D. H. Keisler and H. Jammes, 2003. Growth hormone and milking frequency act differently on goat mammary gland in late lactation. J. Dairy Sci., 86: 509-520.

Delamaire, E. and J. Guinard-Flament, 2006. Longer milking intervals alter mammary epithelial permeability and the udder's ability to extract nutrients. J. Dairy Sci., 89: 2007-2016.

Dell'Orto, V., D. Cattaneo, E. Beretta, A. Baldi and E.G. Savoini, 2000. Effects of trace element supplementation on milk yield and composition in camels. Int. Dairy J., 10: 873-879.

Dukwal, V., S. Modi and M. Singh, 2007. A comparative study of nutritional composition of camel and cow's milk. Proceedings of the International Camel Conference, February 16-17, 2007, Bikaner, India, pp: 91 -.

El-Amin, F.M. and C.J. Wilcox, 1992. Milk composition of Majaheim camels. J. Dairy Sci., 75: 3155-3157.

Ereifej, K.I., M.H. Alu'datt, H.A. AlKhalidy, I. Ali and T. Rababah, 2011. Comparison and characterization of fat and protein composition for camel milk from eight Jordanian locations. Food Chem., 127: 282-289.

Farah, Z., 1996. Camel Milk Properties and Products. 1st Edn., SKAT, Swiss Center for Development Cooperation in Technology and Management, Vadianstrasse, Switzerland, ISBN: 9783908001522 , Pages: 91.

Gaili, E.S.E., M.M. Al-Fknah and M.H. Sadek, 2000. Comparative milking performance of three types of saudi camels (Camels dromedaries). J. Camel Pract. Res., 7: 73-76.

Guliye, A.Y., R. Yagil and F.D.D. Hovell, 2000. Milk composition of Bedouin camels under semi-nomadic production system. J. Camel Pract. Res., 7: 209-212. Haddadin, M.S., S.I. Gammoh and R.K. Robinson, 2008. Seasonal variations in the chemical composition of camel milk in Jordan. J. Dairy Res., 75: 8-12.

Hammadi, M., M. Atigui, M. Ayadi, A. Barmat, A. Belgacem, G. Khaldi and T. Khorchani, 2010. Training period and short time effects of machine milking on milk yield and milk composition in Tunisian Maghrebi camels (Camelus dromedaries L.). J. Camel Pract. Res., 17: 1-7.
Iqbel, I., R.A. Gill and M. Younan, 2001. Milk composition of Pakistani camel (Camelus dromedaries) kept under station and Farms condition. Emi. J. Agric. Sci., 13: 7-10.

Karray, N., C. Lopez, M. Ollivon and H. Attia, 2005. La matiere grasse du lait de dromadaire: composition, microstructure et polymorphisme. Une revue. OCL, 12: 441-448.

Kenzhebulat, S., B. Ermuhan and A. Tleuov, 2000. Composition of camel milk and its use in the treatment of infectious diseases in human. Proceedings of the 2nd Camelid Conference on Agroeconomics of Camelid Farming, September 8-12, 2000, AgroMerkur Publ., pp: 101-101.

Khaskheli, M., M.A. Arain, S. Chaudhary, A.H. Soomro and T.A. Qureshi, 2005. Physicochemical quality of camel milk. J. Agric. Soc. Sci., 1: 164-166.

Konuspayeva, G., B. Faye and G. Loiseau, 2009. The composition of camel milk: A meta-analysis of the literature data. J. Food Composit. Anal., 22: 95-101.

Konuspayeva, G., E. Lemarie, B. Faye, G. Loiseau and D. Montet, 2008. Fatty acid and cholesterol composition of camel's (Camelus bactrianus, Camelus dromedaries and hybrids) milk in Kazakhstan. Dairy Sci. Tech., 88: 327-340.

Lorenzen, P., R. Wernery, B. Johnson, S. Jose and U. Wernery, 2011. Evaluation of indigenous enzyme activities in raw and pasteurized camel milk. Small Rumin. Res., 97: 79-82.

Magjeed, N.A., 2005. Corrective effect of milk camel on some cancer biomarkers in blood of rats intoxicated with aflatoxin B1. J. Saudi Chem. Soc., 9: 253-264.

Mal, G., D.S. Sena, V.K. Jain and M.S. Sahani, 2006. Therapeutic value of camel milk as a nutritional supplement for multiple drug resistant (MDR) tuberculosis patients. Israel J. Vet. Med., 61: 88-91.

Mehaia, A.M., A.H. Mohamed, M.A. Kamal and A.E. Samy, 1995. Milk composition of Majaheim, Wadah and Hamra camels in Saudi Arabia. Food Chem., 52: 115-122.

Saoud, A.O., S. Al-Motairy and E. Hashimi, 1988. Camels in Saudi Arabia. Camel News letter, 4: 13-16.

Sawaya, W.N., J.K. Khalil, A. Al-Shalhat and H. Al-Mohammad, 1984. Chemical composition and nutritional quality of camel milk. J. Food Sci., 49: 744-747.

Shabo, Y., R. Barzel, M. Margoulis and R. Yagil, 2005. Camel milk for food allergies in children. Isr. Med. Assoc. J., 7: 796-798. 
Steel, R.G., J.H. Torrie and D.A. Dickey, 1997. Principles and Procedures of Statistics: A Biometrical Approach. 3rd Edn., McGraw-Hill, Singapore.

Stelwagen, K., S.R. Davis, V.C. Farr, C.G. Prosser and R.A. Sherlock, 1994. Mammary epithelial cell tight junction integrity and mammary blood flow during an extended milking interval in goats. J. Dairy Sci., 77: 426-432.
Stelwagen, K., V.C. Farr and H.A. McFadden, 1999. Alteration of the sodium to potassium ratio in milk and the effect on milk secretion in goats. J. Dairy Sci., 82: 52-59.

Zeleke, M.Z., 2007. Major non-genetic factors affecting milk yield and milk composition of traditionally managed camels (Camelus dromedarius) in Eastern Ethiopia. Proceedings of the International Camel Conference, February 16-17, 2007, Bikaner, India, pp: $168-170$. 